\title{
CHARACTERISTICS OF A CLINICAL SAMPLE OF SEXUALLY ABUSED CHILDREN: HOW BOY AND GIRL VICTIMS DIFFER
}

\author{
Kathleen Coulborn Faller, M.S.W., Ph.D. \\ University of Michigan School of Social Work, Ann Arbor
}

\begin{abstract}
The article describes a clinical sample of 87 boy victims of child sexual abuse and compares them to 226 girl victims. Boys were on average 6.3 years of age at onset of the sexual abuse; girls were 5.5 years. Boys were more likely to be victimized by someone outside the family than girls, but about two-thirds of the boys were abused by someone within the family. Male victims were more often abused by someone who sexually abused other children than were female victims. The majority of perpetrators were men; however girls were more likely than boys to be abused by men, and boys by both men and women. Only a small percentage of the offenders were women acting alone, but boys were more likely to be abused by women than girls. In addition, data on the role relationship between victim and offender and how these relationships differ for boy and girl victims are presented.
\end{abstract}

\section{INTRODUCTION}

UNTIL VERY RECENTLY, sexual abuse of boys was virtually unrecognized by professionals involved in child welfare. As late as 1976 when Awad published an article describing a single case of father-son incest, he could only find three similar cases briefly described in the literature. Historically, girl victims of incest by father figures have been the primary focus of inquiry and concern.

The absence of information about males who are sexually abused is in part a consequence of the fact that the major source of data on sexually abused children is the child protection system (American Association for Protecting Children, 1987). It gathers national statistics and reports them annually and has consistently found much higher percentages of girl than boy victims (males being $20 \%$ or less). One reason for the smaller proportion of sexually maltreated boys is that the child protection system has responsibility for those cases where a caretaker is an abuser or is negligent and allows a child to be abused. (This accounts for the small number of adolescent perpetrators and strangers in some child protection data and in this study as well.) Since it appears that boys are more likely to be sexually victimized outside the home than girls (Abel, Mittelman, \& Becker, in press; De Jong, Emmett, \& Hervada, 1982; Ellerstein \& Canavan, 1980; Finkelhor, 1979, 1984; Finkelhor \& Russell, 1984; Geiser 1979; Groth, 1986; Rogers \& Terry, 1984), it is not surprising that these reports note the prevalence of female victimization.

Many of those who do their casefinding using other sources, for example college students (Finkelhor, 1979; Landis, 1956), therapists (Swift, 1979), hospitals (Rogers, 1979; Rogers \& Terry, 1984), adult offenders (Gebhard, Gagnon, Pomeroy \& Christenson, 1965; Groth, 1979;

Received for publication January 1, 1988; final revision received November 14, 1988; accepted November $28,1988$. Reprint requests may be sent to Dr. Kathleen Coulborn Faller, 1065 Frieze Building, Ann Arbor, MI 48109. 
Knopp, 1982), and adolescent offenders (Knopp, 1986; O'Brien, 1986; Porter, 1986), report higher percentages of male victims (between 30 and $50 \%$ ).

An additional reason for the failure to identify and investigate cases with male victims is that boys are more reluctant to report sexual abuse than girls (Finkelhor, 1984; Knopp, 1986; Landis, 1956; Porter, 1986; Rogers \& Terry, 1984; Swift, 1979). This reticence emanates from the fact boys are socialized not to reveal doubts, weaknesses, and fears, and the fact that, since most of the abusers are male, boys have the additional taboo of homosexuality to overcome if they tell.

Researchers and clinicians are just beginning to try to understand the special characteristics of sexual maltreatment of boys (Farber, Showers, Johnson, Joseph, \& Oshins, 1984; Finkelhor, 1979, 1984; Friedrich, Beilke, \& Urquiza, 1987; Geiser, 1979; Johnson \& Shrier, 1985, 1987; Reinhart, 1987; Risin \& Koss, 1987; Rogers \& Terry, 1984; Showers, Farber, Joseph, Oshins, \& Johnson, 1983; Shrier \& Johnson, 1987; Spencer \& Dunklee, 1986). This article will attempt to add to that knowledge by reporting on a clinical sample of sexually abused boys and by making comparisons to a larger sample of sexually victimized girls. Comparisons with the findings of other researchers will also be noted.

\section{METHOD}

The sample consists of validated cases of sexual abuse referred to the University of Michigan Interdisciplinary Project on Child Abuse and Neglect (IPCAN) from agencies in Michigan, Ohio, and Ontario between the years 1979 and 1986. Cases were validated based primarily upon the child's statements and behavior in a clinical interview, although other evidence such as perpetraor confession, corroborating witnesses, and medical findings were also relied upon where present. For a full discussion of the clinical procedures employed to validate the sexual abuse in these cases, see K. C. Faller, 1988. Project staff have particular expertise in child sexual abuse and provide diagnostic and treatment services on cases referred primarily from community agencies. In addition, data are systematically collected for research purposes.

Some calculations were undertaken to provide a rough estimate of the possible universe of cases of sexual abuse of boys during the time frame of the study. Of the 19,368 victimization cases referred to Michigan Childrens' Protective Services which supplied $80 \%$ of the cases, $11 \%$ or 2,130 were boys. The substantiation rate for referrals was around $40 \%$, which would mean 852 confirmed cases of boy victimization. Thus the number of cases identified by protective services was about 10 times the size of our sample which came entirely from the one agency IPCAN.

Cases included met the following definition of sexual abuse: (1) There was an age differential of at least five years between the victim and offender; and (2) the abuse involved some sort of sexual contact--fondling of the intimate parts, oral-genital sexual contact, or penetration of the vagina or anus by finger(s), penis, or object. A number of cases also involved noncontact behaviors, such as making sexual remarks, exposure, voyeurism, and picture taking, but in all of those instances contact behaviors were also present. A requirement that the sexual contact be unwanted was not part of the definition.

At the time of the study, sexual abuse of 313 victims had been confirmed: 87 (27.8\%) males and 226 females $(72.2 \%)$. Of the male victims $38(43.7 \%)$ were referred by child protection agencies (sometimes in conjunction with other agencies); $14(16.1 \%)$ came from other diagnostic or treatment agencies; $13(14.9 \%)$ from courts or the police; $8(9.2 \%)$ from attorneys; and $14(16.1 \%)$ were self-referrals, including 8 situations where the perpetrator referred himself and his victims. Comparable percentages of females were referred by other agencies 
(14.2\%) and self (14.6\%), but a larger proportion came from protective services $(65.5 \%)$ and smaller percentages from courts and attorneys ( $5.8 \%$, combined).

In 21 boy victim cases $(24.1 \%)$ the victim, the offender, and a nonoffending parent were interviewed; and in 21 cases $(24.1 \%)$ the victim and the offender were evaluated. In these situations, the perpetrator was usually a family member. In 35 cases $(40.2 \%)$ the child and parent(s) were interviewed. These were instances where the offender was someone outside the family. Finally in 10 cases $(11.5 \%)$, only the victim was assessed. These were generally ones of intrafamilial sexual abuse where the victim was already in foster care and the parents either refused to be seen or were assessed by someone else. The persons who were interviewed differed somewhat for cases involving girls. In $41 \%$ of cases, victim, nonoffending parent, and offender were assessed; in $25 \%$, victim and mother; and in $6 \%$, victim and offender. Parent(s) and victim, where the offender was extrafamilial, were interviewed $12 \%$ of the time and victim only $17 \%$. In all cases, other agency records (for example, those from child protective services, the police, and other social agencies) were made available. The amount of client contact ranged from 1.5 hours to 41 hours, the mean length of time being 6.2 hours. When the clinical assessment was completed, a research protocol was filled out on each victim.

Information for the following variables was coded for this analysis: (1) race, (2) socioeconomic status, (3) age at onset of sexual abuse, (4) whether the sexual abuse was intrafamilial or extrafamilial, (5) whether or not there was more than one victim, (6) whether or not there was more than one offender, (7) the sex of the offender, and (8) the role relationship between perpetrator and victim.

Descriptive statistics were computed for the 87 boys on these variables. In addition, comparisons between findings for male 87 victims and the 226 female victims were made. (While statistical tests were employed, their limitations are recognized because the cases were not a representative sample.)

\section{RESULTS}

The findings are presented in two sections: (1) characteristics of victims, and (2) the characteristics of the sexually abusive relationships.

\section{Characteristics of Victims}

Data on race, socioeconomic status, and age at onset of the sexual abuse for the 87 boy victims were compared with findings for the 226 female victims.

Race. Of the boy victims $81(93.1 \%)$ were white and $6(6.9 \%)$ black. The findings for the group of female victims were similar: $89.2 \%$ white and $10.7 \%$ nonwhite (black, bi-racial, American Indian) (N.S.). The proportion of nonwhites in the geographical area from which the sample came is approximately 10\% (Andrews \& Boger, 1980).

Socioeconomic status.Precise income data were not available on all of the victims' families, but they were rated either middle class or lower class based upon parental occupation, source of income (e.g., AFDC), living situation, and income level, at the time of IPCAN involvement.

Male victims' families were found to be fairly evenly split, with $40(46 \%)$ being categorized as middle class and $47(54 \%)$ as lower class. The 226 female victims were more likely to be lower class (79.5\%) and less likely to be middle class $(20.5 \%)$ than boys (chi-square $=19.2, p$ $=.0000$ ). The reason for this difference is probably, as will be noted below, a higher percentage of girls were sexually abused within the family. Most intrafamilial sexual abuse cases were 
Table 1. Distribution for Age at Onset for Male Victims of Sexual Abuse

\begin{tabular}{lllll}
\hline Age Group & $2-3$ & $4-5$ & $6-10$ & $11-17$ \\
\hline Number & 22 & 28 & 22 & 15 \\
Percentage & 25.3 & 32.2 & 25.3 & 17.2 \\
\hline
\end{tabular}

referred by child protection agencies, and poor families are more likely to be reported to child protection agencies than affluent ones when they are abusive (Faller, 1988; Pelton, 1978).

This interpretation is supported by a comparison of socioeconomic status for intra- versus extrafamilial sexual abuse cases for the male victims. Those sexually abused within the family were more likely to be lower class than those victimized outside (intrafamilial $=67.3 \%$; extrafamilial $=31.3 \%$; chi-square $=9.17 ; p=.003$ ).

Age at Onset.The primary source of information about age at onset was the victim. During the course of the clinical assessment, victims were asked to describe the first time the offender sexually abused them, and then supplementary questions were posed to locate the event in time. In addition, in some cases information from nonoffending parents and perpetrators was used to establish age at onset. When there were multiple perpetrators, the child's age when the first abuser first abused was employed.

The mean age at onset for boy victims was 6.3 years, the youngest being 2 and the oldest 17. Victims were also grouped into age categories based upon clinical criteria. The distribution for age at onset by age groups appears in Table 1 .

More than half of the boy victims were under the age of 6 , and almost one-third fell into the 4- and 5-year range. Less than a fifth were adolescents. Thus, these victims were fairly young.

Zavodnick (1986), who collected data on sexually abused boys seen for psychiatric evaluation, as well as Ellerstein and Canavan (1980), De Jong and colleagues (1982), and Rogers and Terry (1984), whose samples were hospital-based, also found male victims to be young. However, even though the boys seen by IPCAN were young, they were not as young as the female victims, whose mean age at onset was 5.5 years, the difference approaching statistical significance $(F=3.67 ; p=.06)$. (The young age of victims seen by IPCAN is probably related to the kinds of cases referred to a specialized diagnositic unit. Young victims might be more difficult to diagnose and such cases might involve more psychopathology.)

Reports in the literature of the relative ages of male and female victims vary. Many are consistent with our finding that boys are somewhat older (Finkelhor, 1979, 1984; Gebhard et al., 1965). Nevertheless, there are also studies (American Humane Association, 1981, in Finkelhor, 1984; De Jong et al. 1982; Ellerstein \& Canavan, 1980; Rogers \& Terry, 1984) which report the opposite; boy victims were found to be younger than girls. Finkelhor (1984) points out that this inconsistency may be caused by the fact that some findings are based upon self-reports while others are statistics from reported cases; the former are self-disclosures of age at onset, while the latter are findings of age at discovery by professionals. Nevertheless, more research needs to be undertaken to determine if boys and girls have different ages of vulnerability to sexual abuse and if so, why.

\section{Characteristics of the Sexually Abusive Relationships}

In order to better understand the sexual abuse of boys and how it differs from that of girls, the situations of victimization were examined from several perspectives. The classification of 
maltreatment was based upon whether it was intrafamilial or extrafamilial, whether there were single or multiple victims, whether there were single or multiple offenders, and the sex of the perpetrator. In addition, cases were examined in terms of the role relationship between victim and perpetrator.

Intrafamilial versus extrafamilial sexual abuse. As noted earlier, other researchers and clinicians have found that boys are more likely than girls to be sexually abused outside the home. Sexual abuse was categorized as intrafamilial whenever there was a blood relationship between the victim and offender or a relationship by marriage between the offender and the victim's family. In addition, if the offender lived within the household, as might be the case with a mother's common-law partner, the case was coded as intrafamilial. One reason for including the latter cases in the intrafamilial category was because the boyfriend was likely to be the child's psychological parent (Goldstein, Freud, \& Solnit, 1973). A second reason was that in some cases both mother and this man were sexually abusing the child, and it made the most sense to call such a case intrafamilial. There were no known cases in our study of boys who were sexually abused both within the family and outside.

Of boy victim cases, $55(63.2 \%$ ) were classified as intrafamilial sexual abuse and $32(36.8 \%)$ as extrafamilial. Even though the majority of victims were classified as intrafamilial, the percentage was not so great as for female victims, $89.1 \%$ of whom were categorized as intrafamilial sexual abuse (chi-square $=26.8, p=.0000$ ). (Of the female victims, $3.5 \%$ were sexually abused both within and outside the family. For the purpose of making comparisons with male victims, these cases were coded according to who appeared to be the primary perpetrator. In all cases this was someone within the family.)

Although the relative proportions of intrafamilial and extrafamilial sexual abuse for males and females were consistent with the findings of other researchers (Ellerstein \& Canavan, 1980; Finkelhor, 1984; Rogers \& Terry, 1984), the absolute percentages of both boys and girls found to be sexually abused outside the home were lower than those reported by others. For example, Finkelhor in a student survey (1979) found that $83 \%$ of persons sexually abusing boys and $56 \%$ of those abusing girls were nonfamily members; and in a survey of Boston area parents (1984), 77\% of offenders against boys were nonfamily members and $66 \%$ of abusers of girls. Similarly, Rogers and Terry (1984) report $75 \%$ of boys and $48 \%$ of girls victimized by someone outside the home; and Ellerstein and Canavan (1980) report $13 \%$ of boys and $25 \%$ of girls victimized by a family member.

However, the proportions of intra- versus extrafamilial sexual abuse for both male and female victims seen by IPCAN were fairly consistent with those of nationally reported child protection cases, $23 \%$ of boys having been sexually abused outside the family and $14 \%$ of girls (American Humane Association, 1981, in Finkelhor, 1984). Similarly, the relative proportions of male and female victims reported in Michigan during the time frame IPCAN cases were seen are comparable, $19.7 \%$ of boys' cases being extrafamilial abuse and $13.4 \%$ of girls' cases (State of Michigan Protective Services Management Information System, 1980-1987). The correspondence of our findings with those of child protection cases probably is related to the fact that the largest proportion of our cases came from child protection agencies.

Intra- and extrafamilial sexual abuse situations of male victims were compared for age at onset. Boys who were sexually abused within the household were significantly younger (5.7 years) than those victimized outside $(7.4$ years $)(F=3.84 ; p=.05)$. This finding is not unexpected since younger children would not be so readily accessible to abusers outside the home as older ones, who leave the home to go to school and involve themselves in other extrafamilial activities. 
Table 2. Multiple Versus Single Sexual Abuse for Male and Female Victims

\begin{tabular}{lccccc}
\hline & \multicolumn{2}{c}{ Males } & & \multicolumn{2}{c}{ Females } \\
\cline { 2 - 3 } \cline { 5 - 6 } & Number & Percentage & & Number & Percentage \\
\hline Intrafamilial, multiple & 45 & 51.7 & & 126 & 55.8 \\
Extrafamilial, multiple & 29 & 33.3 & & 24 & 10.6 \\
Single & 13 & 14.9 & & 76 & 33.6 \\
\hline
\end{tabular}

$\chi^{2}=27.04 ; p=.0000 ; d f=2$.

sociation data that boys were less likely than girls to be solo victims and in fact were generally victimized in conjunction with others, usually their sisters. Similarly, Reinhart (1987) reports the increased probability for males to be co-victims.

For our analysis, cases were categorized into (1) intrafamilial, multiple victim; (2) extrafamilial, multiple victim; and (3) single victim. For a case to be classified as multiple victim, there had to be evidence the offender had sexually abused at least one other child, either by his admission, the report of the other victim, a report from the victim in our sample, or a reliable agency record.

In 45 cases $(51.7 \%)$, boys were sexually abused within the home by someone who abused at least one more victim in the household; and in 29 (33.3\%), the boys were sexually abused by someone outside the home who also victimized others. Only 13 boys (14.9\%) were solo victims. All of these were cases of intrafamilial sexual abuse, and nine of the boys were from one-child families. Thus in this clinical sample, boys were almost always sexually maltreated by those who victimized other children as well; and when they appeared to be single victims, it was usually in a situation where no other potential victim was readily available.

The finding that single-victim males were abused by someone in the household conflicts with Finkelhor's (1984) report on the American Humane Association data. He found that in solo victimization, the abuser was likely to be someone outside the family. In addition, higher percentages in our sample were found to be in multiple abuse situations than in Finkelhor's (85\% versus $60 \%)$.

Our male and female cases were compared on this variable (see Table 2). The data indicate that boys and girls in this sample were about equally likely to be one of several victims within the household. However, boys were significantly more likely than girls to be part of an extrafamilial multiple victimization situation, and girls were more likely than boys to be solo victims. Of the female single-victim cases $90 \%$ were intrafamilial. Finkelhor (1984) found girls to be solo victims $65 \%$ of the time.

Thus these results differ somewhat from those of Finkelhor, but nevertheless are consistent with his findings that boys tend to be sexually abused by perpetrators who abuse others as well. The differences in our rates of multiple victimization for both boys and girls might be explained in two ways. First, a project such as ours, that tends to see difficult cases, might differentially receive multiple victim cases. Second, the extensive evaluation usually involved in our work might uncover multiple victimization missed by a protective services investigation.

When boys in these three different victimization categories were compared for age at onset, statistically significant differences were found. Solo victims (who were all intrafamilial) were the youngest when the sexual abuse began ( 3.6 years). Boys in intrafamilial multiple victimization situations were next in age ( 6.2 years), and those in extrafamilial multiple abuse situations the oldest $(7.7$ years) $(F=5.47 ; p=.006)$. The curious finding here is the very young age of single victims; it may relate to differences in perpetrator characteristics and dynamics of solo and multiple victim cases. 
Single versus multiple offenders. Rogers and Terry (1984) report that boys are more likely than girls to be sexually abused by multiple perpetrators, but other authors (Farber et al., 1984; Reinhart, 1987) do not find this to be the case. To pursue this issue, data were gathered as to whether children were sexually abused by a single person or more than one person, and the findings for boys and girls were compared. One-third (29) of the boys were victimized by more than one person, and $25.8 \%$ of girls were so victimized (N.S.). The percentages for both males and females were higher than those of Rogers and Terry's (males $=20 \%$; females $=13 \%$ ), Farber and colleagues' ( $13 \%$ for both boys and girls), and Reinhart's (males $=7 \%$; females $=5 \%$ ) samples. Why the percentages of abuse by multiple offenders should be higher in our sample is not altogether clear. Perhaps since theirs are hospital samples, they have less opportunity for extended involvement and have less background information and thus are not always aware of multiple offenders.

Sex of the offender. The literature indicates that most sexual abusers are male (Finkelhor \& Russell, 1984; Groth, 1979; Justice \& Justice, 1979; Mayer, 1983), including those who victimize boys (De Jong et al, 1982; Farber et al., 1984; Finkelhor \& Russell, 1984; Finkelhor, 1984; Johnson \& Shrier, 1987; Knopp, 1986; Porter, 1986; Reinhart, 1987; Risin \& Koss, 1987; Rogers \& Terry, 1984; Zaphiris, 1986). Data were collected on offender sex and were categorized as follows: (1) male offender, (2) female offender, and (3) both male and female offenders. Men sexually abused $55(63.1 \%)$ of the boys, and women only $7(8 \%)$ boys. Zavodnick (1986), De Jong and colleagues (1982), Reinhart (1987), Farber and colleagues (1984), and Spencer and Dunklee (1986) found comparable small percentages of boys to have been victimized by females. However, Risin and Koss (1987) and Johnson and Shrier (1987) found larger proportions of female perpetrators, $42.7 \%$ and $45.8 \%$, respectively. Risin and Koss, whose sample consisted of college students, used a very broad definition of sexual abuse, which encompasses some consensual activities with adolescent females. Johnson and Shrier's population was restricted to adolescents and consists of 24 cases. Thus the divergence in their findings might be accounted for by unique characteristics of their research, but the issue of women abusing boys is one that requires further research.

In our sample 25 boys $(28.7 \%)$ had experiences with both male and female perpetrators. For all boys, at least some of the encounters were conjoint; for example, the boys were abused by two parent figures, who acted together, or by both male and female teachers at a day care center. The proportion of male victims multiplely abused was larger than that reported by other researchers: Risin and Koss (1987) found 4.2\%, Reinhart (1987) 2\%, and Farber and colleagues (1984) 6\%. Most likely, the high percentage in the IPCAN sample is a function of the setting. The project tends to deal with cases that are diagnostic and treatment challenges and those where expert opinion and testimony will be required. In addition, the investigation done by IPCAN is more extensive than that likely in a hospital setting or the research questions of Risin and Koss, and therefore perhaps more likely to uncover more details about the boys' abuse.

Sex of the offender was compared for boy and girl victims and significant differences were found (see Table 3 ). The findings indicate that female victims were more likely than males to be sexually abused by a man; neither boys nor girls were very likely to be victimized by a woman alone, but this happened with boys ten times more often than with girls; and boys appear more likely to have been sexually abused by perpetrators of both sexes. The findings regarding male versus female offenders and male versus female victims are consistent with other reports (Finkelhor \& Russell, 1984).

Role relationship between victim and offender. Boys were sexually maltreated by persons who had a variety of role relationships with them. These were fathers, stepfathers, mothers, step- 
Table 3. Offender Sex for Male and Female Victims

\begin{tabular}{lccccc}
\hline & \multicolumn{2}{c}{ Male Victim } & & \multicolumn{2}{c}{ Female Victim } \\
\cline { 2 - 3 } \cline { 6 - 7 } Offender Sex & Number & Percentage & & Number & Percentage \\
\hline Male & 55 & 63.2 & & 187 & 81.7 \\
Female & 7 & 8.0 & & 2 & .9 \\
Male \& Female & 25 & 28.7 & & 40 & 17.5 \\
\hline
\end{tabular}

$\chi^{2}=18.08 ; p=.0001 ; d f=2$.

mothers, other relatives, family friends or acquaintances, and persons who had a professional relationship with the child. The category, stepfathers, includes mothers' boyfriends, adoptive fathers, and foster fathers, as well as stepfathers. Similarly, in the stepmother group were father's girlfriends. There were no cases of sexual abuse by adoptive or foster mothers in this sample. The professionals were teachers, day care providers, camp counselors, and scout leaders.

Because boys (as well as girls) might be abused by more than one person, a coding system which employed the perpetrator-victim dyad as the unit for this analysis was used. (Almost $60 \%$ of the perpetrators sexually abused more than one child in the sample-about a fourth were cases where the offenders abused both within their family and outside-and more than a fourth of the children were sexually abused by more than one person. When the perpetratorvictim dyad is used as the unit of analysis, the sample expands from 313 victims to 450 perpetrator-victim dyads.) As many as three different abusers could be coded for each victim. Some children were concurrently sexually maltreated by two or more perpetrators while others were serially abused by more than one person. There were 23 cases ( 10 involving boy victims and 13 involving girls) where two parenting figures and sometimes others conjointly sexually abused children. In cases where professionals victimized children, there was also some concurrent abuse by more than one perpetrator; 28 children were abused by more than one perpetrator in day care settings. There were also an additional eight miscellaneous cases involving concurrent multiple perpetrators. The distribution for role relationship between perpetrator and victim for boys is found in Table 4.

The largest proportion of perpetrators were professionals who consisted of more than a fourth of the offenders. The next largest number were biological fathers, also more than a quarter. Approximately half of these fathers (18) were living with their children, and about half (16) were noncustodial fathers. Zavodnick (1986) found the largest percentage of abusers of the boys she studied to be biological fathers; Reinhart (1987) and Spencer and Dunklee (1986) reported fathers to represent the greatest number of intrafamilial offenders, but as already noted, found abuse by someone outside the household more common. Stepfathers were the next most numerous type of abuser in this sample; they were also noted to be a large proportion of offenders by Reinhart (1987).

Table 4. Role Relationship between Victim and Perpetrator

\begin{tabular}{llcccccc}
\hline & & & \multicolumn{1}{c}{ Role } \\
\cline { 2 - 8 } & Father & Step-father & Mother & Step-mother & $\begin{array}{c}\text { Other } \\
\text { Relative }\end{array}$ & Non-relative & Professional \\
\hline No. & 34 & 21 & 13 & 3 & 7 & 15 & 37 \\
$\%$ & 26.2 & 16.2 & 10. & 2.3 & 5.4 & 11.5 & 28.6 \\
\hline
\end{tabular}


Table 5. Role Relationship Between Perpetrator and Victim for Male and Female Victims

\begin{tabular}{lrrrrr} 
& \multicolumn{2}{c}{ Male } & & \multicolumn{2}{c}{ Female } \\
\cline { 2 - 3 } \cline { 6 - 6 } \multicolumn{1}{c}{ Role } & No. & $\%$ & & No. & $\%$ \\
\hline Bio-father & 34 & 26.2 & & 121 & 37.8 \\
Stepfather & 21 & 16.2 & & 72 & 22.5 \\
Bio-mother & 13 & 10. & & 16 & 5. \\
Stepmother & 3 & 2.3 & & 0.6 \\
Other relative & 7 & 5.4 & & 43 & 13.4 \\
Non-relative & 15 & 11.5 & & 33 & 10.3 \\
Professional & 37 & 28.5 & & 33 & 10.3 \\
\hline
\end{tabular}

None of the perpetrators in this study were unknown to the victim. In contrast, Rogers and Terry (1984), Risin and Koss (1987), Farber and colleagues (1984), and Ellerstein and Canavan (1980) found that a substantial number of boys ( 1.5 to $56 \%$ ) were sexually abused by strangers; however, as mentioned earlier, all except Risin and Koss's sample were hospitalbased populations. Such facilities would be more likely to see children subjected to sexual assault by strangers than would our program which receives the largest proportion of its referrals from child protection agencies.

A comparison was made of the role relationship between victim and offender for male and female victims. As can be seen in Table 5, there were differences in offender role relationship for boys and girls. Girls were more likely than boys to be sexually abused by their biological fathers, these men consisting of more than a third of the abusers of girls but a little more than a quarter of boys' abusers. Boys appear to be more likely than girls to be victimized by their mothers, whereas girls were more frequently molested by other relatives than boys. In addition, a higher proportion of the abusers of boys had a professional role vis-a-vis the victim (more than a fourth), than did abusers of girls (about a tenth). These findings reinforce those cited earlier documenting boys as being more frequently sexually abused by someone outside the family than girls.

\section{SUMMARY AND CONCLUSIONS}

The investigation of these 87 sexually abused boys reveals that they have distinct characteristics. Moreover, situations of male victimization can be differentiated from those of females in a number of ways.

The 87 males were predominately white $(93.1 \%)$ and about evenly divided between middle and lower class. They were young when first sexually abused, their mean age being 6.3 years.

About two-thirds of the boys were sexually abused within their families, and about onethird by someone outside. Only a small percentage (14.9\%) were the only victim of their abuser; about half were part of a multiple victim situation within the family; and about a third of a multiple victim situation outside. One-third of the boys were sexually abused by more than one person. About two-thirds of them were victimized by males; only $8 \%$ by females, and more than a fourth by both men and women.

More than a fourth of the offenders were professionals, and almost as large a proportion were the boys' fathers. Stepfathers were somewhat less than a fifth of the abusers.

When the 87 boys were contrasted with a sample of 226 girl victims, boys were more likely to come from middle class backgrounds than girls ( $46 \%$ versus $20.5 \%$ ). Male victims were also older at onset of the sexual abuse than females (6.3 years versus 5.5 years). 
Although the majority of male and female victims were sexually maltreated within the family, boys were more likely than girls to be victimized by someone outside the home ( $36.8 \%$ versus $10.9 \%$ ). As to whether the child was a solo victim or one of several, about half of both boys and girls were sexually maltreated in multiple intrafamilial situations; but boys were more often victims of multiple extrafamilial sexual abuse, and girls more often solo victims. The majority of abusers of both male and female children were men; however, girls ( $81.7 \%)$ were more likely to be abused by men than were boys $(63.2 \%)$. Only a small percentage of sexual abusers of either male or female victims were women, but boys were ten times more likely to be maltreated by women. Victims of both sexes might be sexually abused by perpetrators of both sexes, but this was more likely to happen to boys $(28.7 \%)$ than girls $(17.5 \%)$.

The perpetrator-victim role relationships differed for boys and girls. Girls were more likely to be sexually abused by their fathers $(37.8 \%)$ than boys $(26.2 \%)$, and boys were more frequently victimized by professionals $(28.5 \%)$ than girls $(10.3 \%)$.

The findings from these clinical cases add to the knowledge that is accumulating about the unique characteristics of sexual victimization of boys and how they differ from girls. However, a number of inconsistencies are found between this study and previous ones, as well as among the other studies. To a considerable extent, they are a consequence of the differing sources of the samples and argue for continued research with larger samples from both clinical and general populations. As studies accumulate, a substantial number of these inconsistencies should be resolved.

Despite the progress that has been made in recent years in cataloging the characteristics of sexual abuse, an important question, which is still unanswered, is why boys differ from girls in their sexual victimization. Does the etiology lie in behavior or characteristics of the victims or in the psychopathology of the perpetrators or some interaction? This is a much more difficult question to answer and is perhaps the next challenge for researchers exploring the differences between male and female sexual victimization.

\section{REFERENCES}

Abel, G. G., Mittelman, M., \& Becker, J. V. (1986). Sex offenders: Results of assessment and recommendations for treatment. Unpublished manuscript. New York Psychiatric Institute, New York.

American Association for Protecting Children. (1987). Highlights of official child neglect and abuse reporting: 1985. Denver: American Humane Association.

American Humane Association. (1981). National study on child neglect and abuse reporting. Denver: American Humane Association.

Andrews, M. \& Boger, R. (1980). Michigan family sourcebook. Lansing, MI: Michigan State University.

Awad, G. (1976). Father-son incest: A case report. Journal of Nervous and Mental Diseases. 162(2), $135-139$.

De Jong, A., Emmett, G., \& Hervada, A. (1982). Sexual abuse of children. American Journal of the Disabled Child, 136, 129-134.

Ellerstein, N., \& Canavan, W. (1980). Sexual abuse of boys. American Journal of the Disabled Child, 134, $255-257$.

Faller, K. C. (1988). Child sexual abuse: An interdisciplinary manual for diagnosis, case management, and treatment. New York: Columbia University Press.

Farber, E., Showers, J., Johnson, C., Joseph, J., \& Oshins, L. (1984). The sexual abuse of children: A comparison of male and female victims. Journal of Clinical Child Psychology, 13(3), 294-297.

Finkelhor, D. (1984). Boys as victims: A review of the evidence. In D. Finkelhor, Child sexual abuse: New theory and research. New York: The Free Press.

Finkelhor, D. (1979). Sexually victimized children. New York: The Free Press.

Finkelhor, D., \& Russell, D. (1984). Women as perpetrators. In D. Finkelhor, Child sexual abuse: New theory and research. New York: The Free Press.

Friedrich, W., Beilke, R., \& Urquiza, A. (1987). Behavior problems of sexually abused bovs. Unpublished manuscript, The Mayo Clinic, Rochester, NY.

Gebhard, P., Gagnon, J., Pomeroy, W., \& Christenson, C. (1965). Sex offenders. New York: Harper and Row.

Geiser, R. (1979). Hidden victims. Boston: Beacon Press.

Goldstein, J., Freud, A., \& Solnit, A. (1973). Beyond the best interests of the child. New York: The Free Press. 
Groth, N. (1986). Forward. In E. Porter (Ed.). Treating the young male victim of sexual assault: Issues and intervention strategies. Syracuse: Safer Society Press.

Groth, N. (1979). Men who rape. New York: Plenum.

Johnson, R., \& Shrier, D. (1987). Past sexual victimization by females of male patients in an adolescent medicine clinic population. American Journal of Psychiatry, 144(5), 650-652.

Johnson, R., \& Shrier, D. (1985). Sexual victimization of boys. Journal of Adolescent Health, 6, $372-376$.

Justice, B., \& Justice, R. (1979). The last taboo. New York: Human Sciences Press.

Knopp, F. H. (1986). Introduction. In E Porter (Ed.), Treating the young male victim of sexual assault: Issues and intervention strategies. Syracuse: Safer Society Press.

Knopp, F. H. (1982). Remedial intervention in adolescent sex offenses: Nine program descriptions. Syracuse: Safer Society Press.

Landis, J. (1956). Experiences of 500 children with adult sexual deviants. Psychiatric Quarterly Supplement, 30, 91 . 109.

Mayer, A. (1983). Incest: A Treatment Manual for Victims, Spouses, and Offenders. Holmes Beach, FL: The Learning Press.

O'Brien, M. (1986). Treatment programs for adolescent sex offenders. Workshop for the Statewide Advisory Board on Sexual Abuse Programs, Lansing, MI.

Pelton, L. (1978). Child sexual abuse: The myth of classlessness. American Journal of Orthopsychiatry, 48(4), 608617.

Porter, E. (1986). Treating the young male victim of sexual assault: Issues and intervention strategies. Syracuse: The Safer Society Press.

Reinhart, M. (1987). Sexually abused boys. Child Abuse \& Neglect, 11, 229-235.

Risin, L., \& Koss, M. (1987). The sexual abuse of boys. Journal of Interpersonal Violence, 2(3), 309-323.

Rogers, C. (1979). Findings from a hospital-based sexual abuse treatment program. Paper presented at the First National Conference on the Sexual Victimization of Children, Washington, DC.

Rogers, C., \& Terry, T. (1984). Clinical intervention with boy victims of sexual abuse. In I. Stuart \& J. Greer (Eds.), Victims of sexual aggression: Treatment of children, women, and men. New York: Van Nostrand Reinhold.

Showers, J., Farber, E., Joseph, J., Oshins, L., \& Johnson, C. (1983). The sexual victimization of boys: A three-year survey. Health Values, 7, 15-18.

Shrier, D., \& Johnson, R. (1987, July 8). Sexual victimization of boys: An adolescent medicine population. Paper presented at the Third National Family Violence Research Conference, Durham, NH.

Spencer, M., \& Dunklee, P. (1986). Sexual abuse of boys. Pediatrics, 78(1), 133-137.

State of Michigan Protective Services Management Information System. (1979-1987). Michigan Department of Social Services, Lansing, MI.

Swift, C. (1979). Sexual victimization of children: An urban mental health survey. In L. Schultz (Ed.), The sexual victimology of youth. Springfield, IL: Charles Thomas.

Zaphiris, A. (1986). The sexually abused boy. Preventing Sexual Abuse, 1(1), 1-4.

Zavodnick, J. (1986). Male victims of sexual abuse: 51 case reports. Children and Teens Today Newsletter, 6(12), 4-6.

Résumé-Le présent article décrit un échantillon clinique de 87 garçons victimes de sévices sexuels et les compare avec 226 filles. L'âge moyen des garçons était de 6.3 ans au début de la maltraitance; celui des filles était de 5.5 ans. La probabilité que les garçons soient agressés par une personne n'appartenant pas à la famille était plus grande que dans le cas des filles. Cependant, environ $\frac{?}{3}$ des garçons ont subi des sévices de la part d'une personne apparentée. Les victimes du sexe masculin étaient plus souvent attaquées par quelqu'un qui avait également maltraité sexuellement d'autres enfants. Ce n'était pas le cas dans la cohorte des filles. La plupart des assaillants étaient des hommes. Les filles ont été plus souvent agressées par des hommes que les garçons; ces derniers, à la fois par des hommes et des femmes. Seul, un petit pourcentage des assaillants était des femmes agissant seules, mais les garçons couraient plus le risque d'être assaillis par des femmes que les filles. En plus, l'auteur présente des données sur le rôle relationnel existant entre la victime et l'assaillant, et la manière dont ces relations diffêrent selon qu'il s'agit de garçons ou de filles.

Resumen-El artículo describe una muestra clínica de 87 niños víctimas del abuso sexual y los compara con 226 niñas víctimas. Los niños tenían una edad media de 6.3 años al comienzo del abuso sexual; las niñas tenian 5.5 años. Los niños habían sido más frecuentemente victimizados por alguien que no pertenecía a la familia que en el caso de las niñas. aunque dos tercios de los niños habían sido abusados por alguien dentro de la familia. Los niños habian sido más frecuentemente abusados por alguien que también abusaba a otros niños que en el caso de las niñas. La mayoría de los perpetradores fueron hombres; aunque las niñas tenían un chance más grande de ser abusadas por hombres, y los niños por ambos hombres y mujeres. Tan solo un pequeño porcentaje de los perpetradores fueron mujeres actuando solas. pero los niños tenían un chance major de ser abusados por mujeres que las niñas. Asimismo presentan datos acerca de los papeles jugados por la víctima y el perpetrador en su relación, y se describe como estas relaciones difieren en el caso de los niños y las niñas victimas. 